\title{
Effects of thermal processing on digestibility and protein utilization of rapeseed meal of medium and low glucosinolate type in diets for growing pigs
}

\author{
MATTI NÄSI and HILKKA SILJANDER-RASI \\ University of Helsinki, Department of Animal Husbandry \\ SF-00710 Helsinki, Finland
}

\begin{abstract}
The nutritive value of rapeseed meals (RSM) from Brassica campestris, 0 and 00 -cultivars, with medium $(25-55 \mu \mathrm{g} / \mathrm{g}$ defatted meal) and low $(<25 \mu \mathrm{g} / \mathrm{g})$ level of glucosinolates (GL), normal solvent extracted meal or thermal treated in order to decrease protein ruminal degradability (Öpex-process) or followed also by treating for GL-reduction, was investigated in three digestibility and balance trials with growing pigs. The GL-reduction treatment used removed 0.68 of the original GL, while Öpex treated RSM's had 0.33 to 0.45 lower total GLcontent than untreated RSM's. The various cultivars or differently processed RSM's were close to each other in their proximate composition. However, thermal treated 0-RSM had a slightly reduced lysine content compared to untreated meal. The efficient degradability of dry matter in the untreated RSM's was on average 0.532 and that of the Öpex-treated 0.485 . The digestibility of CP in different RSM's varied from 0.677 to 0.842 with no significant difference between 0 and 00-RSM's or to the RSM treated for GL-reduction (P>0.05), although 00-RSM's tended to have higher $\mathrm{OM}$ and $\mathrm{CP}$ digestibilities compared with 0-RSM; pooled mean values being 0.638 vs. 0.715 for $\mathrm{OM}$ and 0.715 vs. 0.775 for CP. RSM treated for ruminant escape protein had the same or better digestibility than untreated RSM; pooled average values being 0.669 vs. 0.680 for $O M$ and 0.746 vs. 0.757 for $C P$. This observation has practical importance since the same treatments of RSM could be employed for meals to be used in diets of both ruminants and pigs. In these experiments, the protein utilization was efficient and differences between the dietary treatments were small and insignificant. Heat treatment (Öpex) did not decrease protein utilization despite a small reduction in lysine content.
\end{abstract}

Index words: rape seed meal, glucosinolate, thermal processing, digestibility, pig

\section{Introduction}

Production of rapeseed is one of the most readily available means of increasing the domestic supply of protein of high biological value in Finland. The harvested seed is rich in oil and protein, the former being increasingly used for human consumption. Production of rapeseed oil for fuel purposes is also under evaluation, which means increased oil 
seed meal supply as a protein source for animal feeding. Removal of the oil leaves rape seed meal (RSM) containing 350-400 g/ kg crude protein with an amino acid balance that compares well with that of soybean meal. Whilst RSM is currently included in ruminant rations with promising response (TUORI et al. 1989, unpubl. Huhtanen et al. 1991), the use in pig and poultry rations has not been realised because of the presence of a number of undesirable factors. However, many investigations have shown RSM as a potential replacement for e.g. soybean meal (KIISKINEN 1984, NÄsı et al. 1985).

Rapeseed meal has some antinutritional factors and toxic constituents which restrict the utilization of RSM as feed for pigs. The main factors responsible for lowering the nutritive value are the hulls with a high fibre content of the rapeseed, the glucosinolates (GL), tannins, rapeseed gums, myrosinase and phytic acid (Fenwick and Curtis 1980, Bell 1984).

The most important factor limiting the potential RSM as a protein supplement in pig feeding is the presence of glucosinolates (RUNDGREN 1983). These compounds are broken down by the enzyme myrosinase into toxic, goitrogenic substances which cause metabolic disturbances and depress food intake and growth rate. Some of these are goitrogenic and others are potentially hepatotoxic, whilst the majority are volatile and have a strong bitter taste (BELL 1984). Plant breeding has managed to develop varieties with lower levels of GL. Meals prepared from rapeseed varieties with low or medium contents of GL are finding increasing acceptance as a protein source in pig diets and are being used as replacements for soybean meal (SBM) (TномКE 1984, NÄSI et al. 1985, RowAN and LAWRENCE 1986).

An improvement in the nutritional quality of RSM would be expected from a reduction in the glucosinolate content. In addition, a variety of processes have been reported for the removal of glucosinolates from rapeseed products. Such processes, generally termed detoxification, involve chemical, microbiolog- ical or physical treatments alone, or in combination (FenwiCK et al. 1986).

The fibre content of RSM is almost double that of SBM which lowers the nutrient digestibility and energy value. Rapeseed contain hulls $165-187 \mathrm{~g} / \mathrm{kg}$, on dry matter basis (APPELQVIST and OHLSON 1972). After oil extraction, the resulting meal contains about 300 $\mathrm{g} / \mathrm{kg}$ of hulls. Rapeseed hulls contain about 200 cellulose, 230 lignin, 90 pectin, 200 protein and 50 ash $\mathrm{g} / \mathrm{kg}$, but very little free carbohydrates or lipids. Pectins, cellulose and arabinose-based carbohydrates are dominant carbohydrates in hull-free RSM and these are not regarded as being readily digested by enzymes secreted by the intestine of pig. Insoluble fibre tends to increase transit time and form an insulating coat on the digestible nutrients, thus reducing the nutrient supply. Soluble fibres slow down the transit time, but their gelling, ion-exchange and absorbing characteristics retard digestion and absorption. The breeding work directed towards reduction of hull content may also make RSM more suitable for pig feed. Attempts to dehull rapeseed have been directed toward the same goal.

Proper processing is of great importance to the nutritional value of rapeseed meals for pig diets, and heat treatment in oil extraction and meal toasting inactivates some antinutritional factors in RSM. Heat treatment and hydrothermal processing can be used to rupture the cell wall matrix and modify the chemical structure of the constituents in order to render them more susceptible to enzyme degradation in the small intestine, thus improving the digestibility and utilization of the nutrients, especially amino acids (NÄsı 1991).

The first objective of the present study was to compare the nutrient digestibility of rapeseed meals with various levels of glucosinolates of different varieties before and after processing for GL-reduction. The second objective was to elucidate the effect of thermal processing used in order to decrease protein ruminal degradation on the nutritive val- 
ue of rapeseed meals as protein supplement in pig nutrition.

\section{Material and methods}

The rapeseed meals used in Expt. I, prepared from medium glucosinolate variety 0 type (Brassica campestris), were: 1.) normal solvent-extracted 0-RSM (cv. Emma), 2.) same as 1) but heat-treated (Öpex), to yield a low-degradable rape seed protein for ruminants. The RSM's, prepared from medium or low glucosinolate varieties, in Expt. II. were: 1.) normal solvent-extracted 0-RSM (Emma), 2.) same as 1) but heat-treated (Öpex) 3.) heattreated (Öpex), low rumen degradable 00RSM (cv. Esko), 4.) normal solvent-extracted 00-RSM followed by a process of reduction of glucosinolates (Öljynpuristamo Oy, Helsinki) and in Expt. III 1.) normal solvent-extracted 00-RSM (cv. Esko) and 2.) same RSM as 1.) but heat-treated (Öpex), for low rumen degradable protein.

Öpex process (Öljynpuristamo Oy, Helsinki) is a pressurized heat-moisture treatment, where a sequence of cell rupturing pressure is added to achieve a rapid protein denaturation of the surface molecules. The process is a programmed semi-batch treatment. It also eliminates a part of the antinutrional compounds in the meal as well as producing rumen lowdegradable protein. Ferrous sulphate was used as a supplement at a level of $1.0 \mathrm{~g} / \mathrm{kg}$ meal during toasting to reduce the GL content.

In the first digestibility and balance trial, the normal and Öpex processed 0-RSM's were used at the inclusion level of $202-212 \mathrm{~g} / \mathrm{kg}$ as protein supplements in isonitrogenous, 160 $\mathrm{g} / \mathrm{kg}$ diet crude protein (CP) barley-based diets. In the second digestibility and balance trial, the variously processed 0 - and 00-RSM's were used at the inclusion level of $200 \mathrm{~g} / \mathrm{kg}$ as protein supplements in four isonitrogenous, $152 \mathrm{~g} / \mathrm{kg} \mathrm{CP}$, barley-based diets adjusted with barley protein. The third trial comprised assays of normal and Öpex 00-RSM's at inclusion levels of 203 and $192 \mathrm{~g} / \mathrm{kg}$ providing diets with $160 \mathrm{~g} / \mathrm{kg} \mathrm{CP}$.
The first experiment was made with six castrates from 89 to $109 \mathrm{~kg}$ of live weight with a switch over experimental design and a basal diet assay made separately. The second experiment, in which pigs were at the live weight from 28 to $74 \mathrm{~kg}$, had a $6 \times 6$ Latin square design including a basal diet assay simultaneously. The third trial was made with four pigs of weight between 66 and $89 \mathrm{~kg}$ using a swich over design. Each period comprised 6 days of adjustment and 6 days of total faeces and urine collection.

The coefficients of the apparent digestibility of the nutrients and the nitrogen balance were calculated for each diet and, using the difference method, for each RSM. Assay procedures were similar to those reported by NÄsı (1984), but crude fat was determined after acid hydrolysis. The glucosinolate content was analyzed with high-performance liquid chromatography which separates and quantifies individual components of GL. The degradability of the organic matter in the RSM's was tested by the method of ØrSKov and McDonald (1979).

\section{Results and discussion}

The total GL levels ( $\mu \mathrm{mol} / \mathrm{g}$ defatted meal) of the RSM's made from cv. Emma, a medium GL 0 -type, were between 16 and 55. The 00-RSM's made from cv. Esko, a low GL 00-type contained from 7 to $22 \mu \mathrm{mol}$ of total GL (Table 1). The individual components of GL in relation to others did not vary between varieties. The GL-reduction treatment was reduced to 0.32 of the original total GLcontent compared to untreated. The GL-level of Öpex-treated 0-RSM's was 0.55 of the normal untreated meals. Correspondingly Öpextreated 00-RSM's had a level of 0.67 of the original. No difference in destroying various GL-components were found in present study, they decreased equally in relation to the total content. Lower responses have been reported by Aumaitre et al. (1989) who found microwave treatment decrease the total GL content in RSM by 0.07 , while extrusion has removed 0.19 of these antinutritive factors, principal- 
ly procoitrin (Aumaitre et al. 1989). Extrusion has been shown to inactivate myrosinase efficiently but has had relatively little effect on glucosinolate content, unless chemicals were added before extrusion (FENWICK et al. 1986). They also found that the combination of alkali and ferrous sulphate produces a decrease in total GL-content to 0.80 . This later figure is at the same level as shown in present trial using ferrous sulphate supplementation during toasting the meal.

The chemical composition of the experimental feeds and their calculated feed values are presented in Table 1 . Only small differences were found in the proximate composition of the processed RSM's. Oil was left in meal in solvetizing $101-125 \mathrm{~g} / \mathrm{kg}$ to increase the energy density of RSM. The different RSM's were close to each other in their amino acid composition. However, the RSM treated for ruminants had a slightly lower lysine and available lysine content compared to the untreated normal meal. Excessive heat treatment during processing can lead to the destruction of amino acids and the formation of biologically unavailable amino acid carbohydrate complexes, which was noticed by NÄsı et al (1985) and NÄsı (1991). The mean efficient degradability of the dry matter in untreated RSM's was 0.532 (s.d. 0.0129) and somewhat lower in Öpex-treated RSM's, on average 0.485 (s.d. 0.0217). TUORI (1991, unpublished) found similar degradabilities of the RSM's with equal processing as in present study, but the process of RSM for lower rumen degradability with the Öpex-treatment did not show any response in milk production in that study.

The digestibility of crude protein in the different RSM's varied from 0.677 to 0.842

Table 1. Chemical composition and calculated values of the experimental feeds (Experiments 1, 2 and 3).

\begin{tabular}{|c|c|c|c|c|c|c|c|c|c|c|}
\hline & & \multirow{2}{*}{\multicolumn{2}{|c|}{$\begin{array}{c}\text { Experiment } \\
0-\text { RSM }\end{array}$}} & \multicolumn{4}{|c|}{ Experiment 2} & \multirow{2}{*}{\multicolumn{2}{|c|}{$\begin{array}{c}\text { Experiment } 3 \\
00-\text { RSM }\end{array}$}} & \multirow[t]{3}{*}{ Barley } \\
\hline & & & & \multicolumn{2}{|c|}{$0-\mathrm{RSM}$} & \multicolumn{2}{|c|}{00 - RSM } & & & \\
\hline & & Norm & Öpex & Norm & Öpex & Öpex & $\begin{array}{l}\text { Glucos. } \\
\text { reduct. }\end{array}$ & Norm & Öpex & \\
\hline \multicolumn{11}{|c|}{ Total glucosinolates } \\
\hline Gluconapin & & 15 & 7 & 8 & 6 & 4 & 2 & 6.3 & 4.6 & \\
\hline Glucobrassicanapin & & 14 & 7 & 8 & 4 & 3 & 1.5 & 4.1 & 2.8 & \\
\hline Progoitrin & & 18 & 9 & 10 & 5 & 4 & 2 & 8.0 & 5.9 & \\
\hline Napoleiferin & & 4 & 2 & 2 & 1 & 1 & 1.5 & 0.9 & 0.7 & \\
\hline Others & & 0 & 0 & 0 & 0 & 1 & 1 & 3.0 & 1.8 & \\
\hline \multicolumn{2}{|c|}{ Crude protein, $\mathrm{g} / \mathrm{kg} \mathrm{DM}$} & 361 & 353 & 336 & 340 & 335 & 331 & 325 & 337 & 130 \\
\hline Ether extract & & 100 & 118 & 107 & 101 & 106 & 119 & 125 & 107 & 37 \\
\hline Crude fibre $\quad "$ & & 130 & 130 & 124 & 125 & 121 & 123 & 125 & 123 & 47 \\
\hline Nitrogen free extract & & 335 & 325 & 353 & 352 & 354 & 344 & 349 & 354 & 759 \\
\hline Neutr. deterg. fibre & $n$ & 243 & 240 & 256 & 267 & 249 & 236 & 257 & 265 & 187 \\
\hline Acid deterg. fibre & $"$ & 176 & 173 & 183 & 187 & 176 & 166 & 170 & 172 & 42 \\
\hline Acid deterg. lignin & $"$ & 77 & 73 & 74 & 76 & 66 & 58 & 74 & 72 & - \\
\hline \multicolumn{2}{|l|}{ Lysine, $\mathrm{g} / 160 \mathrm{~g} \mathrm{~N}$} & 56 & 54 & & & & & & & 41 \\
\hline Threonine " & $"$ & 44 & 44 & & & & & & & 35 \\
\hline Methionine " & $"$ & 23 & 24 & & & & & & & 19 \\
\hline Cystine " " & $"$ & 23 & 23 & & & & & & & 24 \\
\hline Available lysine " & $n$ & 53 & 50 & & & & & & & 40 \\
\hline \multicolumn{2}{|l|}{$\mathrm{FU} / \mathrm{kg} \mathrm{DM}$} & 0.84 & 0.86 & 0.73 & 0.71 & 0.89 & 0.90 & 0.95 & 0.98 & 1.14 \\
\hline \multicolumn{2}{|l|}{$\mathrm{Kg} / \mathrm{FU}$} & 1.32 & 1.31 & 1.57 & 1.45 & 1.28 & 1.28 & 1.05 & 1.02 & 1.03 \\
\hline \multicolumn{2}{|l|}{ DCP, g/kg DM } & 265 & 235 & 234 & 230 & 250 & 234 & 262 & 284 & 68 \\
\hline \multicolumn{2}{|l|}{$\mathrm{ME}, \mathrm{MJ} / \mathrm{kg} \mathrm{DM}$} & 12.7 & 13.0 & 12.3 & 12.0 & 13.5 & 13.0 & 13.78 & 14.31 & 14.71 \\
\hline \multicolumn{2}{|c|}{ Efficient degradability DM } & 0.549 & 0.514 & 0.523 & 0.462 & 0.477 & 0.523 & 0.534 & 0.488 & \\
\hline
\end{tabular}


(Tables 2-4). The 00-RSM's tended to have higher organic matter and crude protein digestibilities compared to 0-RSM's; pooled mean values being 0.638 vs. 0.715 for $\mathrm{OM}$ and 0.715 vs. 0.775 for $\mathrm{CP}$, respectively. The treatment for GL-reduction did not have any response to protein digestibility. This is in agreement with the results of SAUER and CICHON (1980), who found no significant differences in the ileal apparent digestibility of essential amino acids between a high and two low GL-RSM. The Öpex-treated 00-RSM had significantly higher protein digestibility $(\mathrm{P}<0.001)$ than other RSM's in Expt. 2. RSM's treated for ruminant escape protein had the same or better digestibility than untreated RSM's; pooled average values being 0.669 vs. 0.680 for OM and 0.746 vs. 0.757 for $\mathrm{CP}$, respectively. This observation has practical importance since the same lots can be used for both ruminants and monogastrics. In Expt. 1 and 3. values of digestion were slightly higher which is to be expected because the pigs were older and made more efficient use of high fibre contents of RSM than younger pigs. Similarily, improvement of CP digestibility by 0.09 units and the ME content by $0.7 \mathrm{MJ}$ per $\mathrm{kg} \mathrm{DM}$ in sows was demonstrated when compared the results on growing pigs (JusT et al. 1983).

Carbohydrate digestibility of all the lots of
RSM's investigated was rather low. However, 00-RSM's tended to show higher digestibility of organic matter, crude fibre and nitrogen free extracts compared to 0-RSM's, but the differences were not statistically significantly (P>0.05). RUNDGREN et al. (1985) also found lower carbohydrate and OM digestibilities for summer HG-RSM in comparison to LG-RSM. The dietary fibre in RSM represents the unavailable part of the diet, which reduces the digestibility of energy and amino acids. Degradation of the structural polysaccharides in rapeseed fibre and the cell wall matrix by physical or other means promotes the release of intracellular nutrients especially that of protein in the small intestine for digestion and absorption (NÄsı 1991). A small insignificant trend to improved NDF digestibility of RSM followed after Öpex-process was noticed.

The present digestibility data of various RSM tested in pigs are in agreement with the recent literature, which shows a superiority in the nutritive value low glucosinolate (LG)compared with high glucosinolate (HG)-RSM (Bourdon and Aumaitre 1990). The average digestibility value of CP of LG-RSM has been 0.79 versus 0.73 for HG-RSM and corresponding average values for content of ME for two RSM-types were calculated to be $\mathbf{1 3 . 1}$

Table 2. Digestibilities of processed rapeseed meals and protein utilization of the diets (Experiment 1).

\begin{tabular}{|c|c|c|c|c|}
\hline & \multicolumn{2}{|c|}{0 -RSM } & \multirow[t]{2}{*}{ SEM } & \multirow{2}{*}{$\begin{array}{l}\text { Statist. } \\
\text { signif. }\end{array}$} \\
\hline & Normal & Öpex & & \\
\hline Organic matter & 0.645 & 0.656 & 0.0039 & NS \\
\hline Crude protein & 0.736 & 0.748 & 0.0059 & NS \\
\hline Ether extract & 0.623 & 0.597 & 0.0073 & NS \\
\hline Crude fibre & 0.321 & 0.362 & 0.0140 & NS \\
\hline Nitrogen free extract & 0.677 & 0.699 & 0.0091 & NS \\
\hline Neutr. deterg. fibre & 0.239 & 0.298 & 0.0165 & NS \\
\hline Acid deterg. fibre & 0.182 & 0.212 & 0.0118 & NS \\
\hline $\mathrm{N}$ intake, $\mathrm{g} / \mathrm{d}$ & 72.2 & 71.8 & 0.30 & NS \\
\hline $\mathrm{N}$ excr. in faeces, $\mathrm{g} / \mathrm{d}$ & 14.5 & 14.2 & 0.19 & NS \\
\hline $\mathrm{N}$ excr. in urine, $\mathrm{g} / \mathrm{d}$ & $32.2 \mathrm{a}$ & $30.7 b$ & 0.21 & $\mathrm{P}<0.05$ \\
\hline $\mathrm{N}$ retained, $\mathrm{g} / \mathrm{d}$ & 25.6 & 26.9 & 0.33 & NS \\
\hline of intake & $0.354 \mathrm{~b}$ & $0.375 \mathrm{a}$ & 0.0036 & $\mathrm{P}<0.05$ \\
\hline of absorbed & $0.444 \mathrm{~b}$ & $0.467 \mathrm{a}$ & 0.0043 & $\mathrm{P}<0.05$ \\
\hline Urea excr. in urine, $\mathrm{g} / \mathrm{d}$ & 55 & 52 & - & - \\
\hline Biological value & 0.529 & 0.550 & 0.0040 & $\mathrm{P}<0.05$ \\
\hline
\end{tabular}


and 11.3 MJ per kg DM, respectively (RUNDGREN 1983). Danish experiments performed according to the regression technique on three different baches of LG-RSM resulted in an estimated average of the CP digestibility of 0.73 and of the ME value of $11.9 \mathrm{MJ}$ per $\mathrm{kg} \mathrm{DM}$ (JusT et al. 1983).

In these experiments, the differences in protein utilization between the dietary treatments were very small. Results of protein utilization in Expt. 1. were poorer than in Expt. 2, but the protein intake was excess to the requirements and pigs were also heavier in that trial. Damages in protein quality were not caused by the thermal treatment in the Öpex process, according the present data. Usually heat treated meals, processed for rumen escape protein, are lower in protein value for pigs compared to untreated (NÄSI et al. 1985, CHANG et al. 1987), probably due to exessive heat which

Table 3. Digestibilities of processed rapeseed meals and protein utilization of the diets (Experiment 2).

\begin{tabular}{|c|c|c|c|c|c|c|}
\hline & \multicolumn{2}{|c|}{0 - RSM } & \multicolumn{2}{|c|}{$00-\mathrm{RSM}$} & \multirow[t]{2}{*}{ SEM } & \multirow{2}{*}{$\begin{array}{l}\text { Statist. } \\
\text { signif. }\end{array}$} \\
\hline & Normal & Öpex & Öpex & $\begin{array}{l}\text { Glucos. } \\
\text { reduct. }\end{array}$ & & \\
\hline Organic matter & 0.630 & 0.619 & 0.703 & 0.660 & 0.031 & NS \\
\hline Crude protein & $0.696 \mathrm{~b}$ & $0.677 b$ & $0.746 a$ & $0.706 \mathrm{~b}$ & 0.007 & $\mathrm{P}<0.001$ \\
\hline Ether extract & 0.656 & 0.624 & 0.670 & 0.678 & 0.036 & NS \\
\hline Crude fibre & 0.336 & 0.332 & 0.497 & 0.389 & 0.061 & NS \\
\hline Nitrogen free extract & 0.649 & 0.650 & 0.730 & 0.692 & 0.053 & NS \\
\hline Neutr. deterg. fibre & 0.335 & 0.408 & 0.526 & 0.400 & 0.069 & NS \\
\hline Hemicellulose & 0.620 & 0.748 & 0.871 & 0.718 & 0.112 & NS \\
\hline Cellulose & 0.440 & 0.512 & 0.630 & 0.510 & 0.064 & NS \\
\hline $\mathrm{N}$ intake, $\mathrm{g} / \mathrm{d}$ & 50.5 & 50.6 & 50.4 & 50.0 & 0.39 & NS \\
\hline $\mathrm{N}$ excr. in faeces, $\mathrm{g} / \mathrm{d}$ & 13.6 & 14.1 & 12.8 & 13.2 & 0.35 & NS \\
\hline $\mathrm{N}$ excr. in urine, $\mathrm{g} / \mathrm{d}$ & 13.8 & 14.1 & 14.0 & 14.1 & 0.59 & NS \\
\hline $\mathrm{N}$ retained, $\mathrm{g} / \mathrm{d}$ & 23.1 & 22.4 & 23.6 & 22.7 & 0.68 & NS \\
\hline of intake & 0.458 & 0.444 & 0.474 & 0.453 & 0.014 & NS \\
\hline of absorbed & 0.634 & 0.620 & 0.637 & 0.621 & 0.017 & NS \\
\hline Urea excr. in urine, $\mathrm{g} / \mathrm{d}$ & 27.4 & 28.8 & 30.1 & 24.8 & 1.40 & NS \\
\hline Biological value & 0.705 & 0.693 & 0.706 & 0.694 & 0.016 & NS \\
\hline
\end{tabular}

Table 4. Digestibilities of processed rapeseed meals and protein utilization of the diets (Experiment 3 ).

\begin{tabular}{lcccc}
\hline & \multicolumn{2}{c}{ 00-RSM } & SEM & Statist. \\
\cline { 2 - 5 } & Normal & Opex & & \\
\hline & & & & NS \\
Organic matter & 0.729 & 0.769 & 0.055 & NS \\
Crude protein & 0.807 & 0.842 & 0.025 & NS \\
Ether extract & 0.604 & 0.645 & 0.053 & NS \\
Crude fibre & 0.328 & 0.370 & 0.083 & NS \\
Nitrogen free extract & 0.769 & 0.796 & 0.075 & NS \\
Crude carbohydrate & 0.714 & 0.750 & 0.077 & NS \\
Neutr. deterg. fibre & 0.278 & 0.381 & 0.1131 & NS \\
Acid deterg. fibre & 0.103 & 0.185 & 0.0940 & NS \\
N intake, g/d & 54.5 & 54.6 & 0.04 & NS \\
N excr. in faeces, g/d & 11.8 & 11.1 & 0.05 & NS \\
N excr. in urine, g/d & 21.0 & 21.3 & 0.78 & NS \\
N retained, g/d & 21.7 & 22.2 & 0.43 & NS \\
$\quad$ of intake & 0.400 & 0.410 & 0.0077 & NS \\
$\quad$ of absorbed & 0.510 & 0.510 & 0.0122 & NS \\
Biological value & 29.6 & 39.7 & 0.0122 & NS \\
\hline
\end{tabular}


destroyes essential amino acids. An improvement in the nutritive quality of RSM would be expected from a reduction in their GLcontent, but the treatment for GL-reduction in this study did not show in the protein utilization. The effect of extraction of RSM with hot 0.70 ethanol and with water has improved net protein utilization in rats significantly compared to untreated RSM (FowLER et al. 1987). Performance was also higher in pigs fed RSM washed with cold water extraction. BILLE et al. (1983) concluded that only minor or no physiological effects in protein utilization in rats were observed at low levels of isolated glucosinolates similar to double low RSM, which is in line with the present observations.

In the present study, where fairly high rape seed meal supplements from cultivars of medium and low GL contents in barley meal diets were used in pig feeding, it can be concluded that RSM is a suitable protein source in supplementing grain protein. Double low cultivar tended to be slightly higher in nutritive value than 0-RSM. The thermal (Öpex process) used to decrease ruminal degradation of RSM protein and organic matter, did not decrease protein utilization so that the same process could be used for RSM used in diets for ruminants and for pigs. From a practical point of view it is also important to retain as high a protein intestinal digestibility as possible, according to the results of the present assay. Processes directed to the decrease glucosinolate content of RSM, did not improve digestibility of nutrients nor protein utilization.

\section{References}

Appelqvist, L.A. \& Ohlson, R. 1972. Rapeseed: Cultivation, composition, processing and utilization. Elsevier Pub. Co. Amsterdam.

Aumaitre, A., Bourdon, D., Peiniau, J. \& Bengala FreIrE, J. 1989. Effect of graded levels of raw and processed rapeseeed on feed digesibility and nutrient utilization in young pigs. Anim. Feed Sci Technol. 24: $275-287$.

Bel., J.M. 1984. Nutrients and toxicants in rapeseed meal: A review J. Anim. Sci. 58: 996-1010.

Bille, N., Eggum, B., Jacobsen, I., Olsen, O. \& Soren. SEN, H. 1983. Antinutritional and toxic effects in rats of individual glucosinolates added to a standard diet. 1. Effects on protein utilization and organ weights. Z. Tierphysiol. Tierenährg. u. Futtermittelkde. 49: 195-210.

Bourdon, D. \& Aumaitre, A. 1990. Low-glucosinolate rapeseeds and rapeseed meals: effect of technological treatments on chemical compaosition, digestible energy content and feeding value for growing pigs. Anim. Feed Sci. Technol. 30: 175-191.

Chang, C.J., Tanskley, T.D. Jr., Knabe, D.A. \& Zebrowska, T. 1987. Effects of different heat treatment during processing on nutrient digestibility of soybean meal in growing swine. J. Anim. Sci. 65: 1273 -1282 .

Finwick, G.R., Curtis, R.F. 1980. Rapeseed meal and its use in poultry diets. A review. Anim. Feed Sci. Technol. 5: 255-298.

-, Simink, E.A., Wilkinson, A.P., Heaney, R.K. \& Le-
GoY, M.A. 1986. Effect of processing on the antinutrient content of rapeseed. J. Sci. Food Agric. 37: 735-741.

Fowler, V.R., Pusxtal, A., McWilliam, R. \& Frank, R. 1987. The use of simple methods of extracting the antinutritive factors in rapeseed meal to improve the growth of pigs and rats. Anim. Prod. 44: 463.

Just, A., Jorgensen, H., Fernandez, J.A., Bech-Andersen, A. \& EngaArd Hansen, N. 1983. Forskellige foderstoffers kemiske sammensaetning, fordoelighed, energi- og proteinvaerdi til svin. 556 Beretn. Stat. Husdyrbrugsf. 99 p.

Huhtanen, P., Khalılı, H. \& Nãsı, M. 1991. A comparison of untreated and formaldehyde-treated barley distiller's solubles and rapeseed meal as protein supplements in dairy cows given grass silage ad libitum. J. Agric. Sci. Finl. 63 (in press).

KIISKINEN, T. 1984. Nutritive and feeding value of some domestic protein sources for poultry in Finland. Helsinki. 40 p.

NAssı, M. 1984. Nutritive value and metabolic effects of whey protein concentrate and hydrolysed lactose for growing pigs. J. Agric. Sci. Finl. 56: 227-238.

- 1991. Digestibility and protein utilization responses of soybean and rape seed meal to physical and enzymatic treatments in diets for growing pigs. J. Agric. Sci. Finl. 63: 465-474.

-, Alaviuhkola, T. \& Suomi, K. 1985. Rapeseed meal of low- and high-glucosinolate type fed to growingfinishing pigs. J. Agric. Sci. Finl. 57: 263-269. 
Rowan, T.G. \& Lawrence, T.L.J. 1986. Growth and metabolism studies in growing pigs given diets containing a low glucosinolate rapeseed meal. J.Agric. Sci., Camb. 107: 483-492.

RUNDGREN, M. 1983. Low-glucosinolate rapeseed products for growing pigs - a review. Anim. Feed Sci. Technol.: 239-263.

-, Askbrant, S. \& Thomke, S. 1975. Nutritional evaluation of low- and high-glucosinolate rapeseed meals with pigs, laying hens and rats. Swedish J. Agric. Res. 15: $61-69$.

Sauer, W.C., Cichon, R. \& Misir, R. 1982. Amino acid availability and protein quality of canola and rapeseed meal for pigs and rats. J. Anim. Sci. 54: 292-301.

Tномке, S. 1984. Further experiments with RSM of Swedish low-glucosinolate type fed to growing-finishing pigs. Swed. J. Agric. Sci. 14: 151-157.

ØrSKov, E.R. \& McDONALD, I.M. 1979. The estimation of protein degradability in the rumen from incubation measurements weighted according to rate of passage. J. Agric. Sci. (Camb.) 92: 499.

Ms received August 12, 1991

\section{SELOSTUS}

\section{Kuumennuskäsittelyn vaikutus eri glukosinolaattipitoisten rypsirouheiden sulavuuteen ja valkuaisen hyväksikäyttöön lihasikojen ruokinnassa}

\section{Matti Näsi ja Hilkka Siljander-Rasi \\ Helsingin yliopisto, kotieläintieteen laitos}

Tutkimuksessa selvitettiin kuumennuskäsittelyn ja glukosinolaattien vähentämisen vaikutusta 0 - ja 00-rypsirouheiden sulavuuteen ja valkuaisen hyväksikäyttöön kasvavilla lihasioilla. Tutkimus käsitti kolme sulavuus- ja tasekoetta, joissa kảytettiin kokonaiskeruumenetelmäă. Tutkittavina lajikkeina olivat 0-rypsi Emma ja 00-rypsi Esko, joissa glukosinolaattien kokonaismaaără oli 16-55 ja $7-22 \mu \mathrm{mol} / \mathrm{g}$ rasvatonta rouhetta. Rouheet olivat normaalisti uuttamalla tuotettuja ja kuumennuskäsittelynä oli Öpex-prosessi, jolla alennettiin rouheiden valkuaisen pötsihajoavuutta. Glukosinolaattien văhentäminen tehtiin käyttăen rautasulfaattikäsittelyă. Rouheet olivat kemialliselta koostumukseltaan lähellä toisiaan. Öpexkäsittely alensi hieman lysiinipitoisuutta käsittelemăttö- mään verrattuna. Rouheiden raakavalkuaisen sulavuus vaihteli 0.677 ja 0.842 välillä. 00 -rouheet olivat sulavuudeltaan hieman parempia kuin 0-rouheet: orgaaninen aine keskimäärin 0.638 vs. 0.715 ja vastaavasti raakavalkuainen 0.715 vs. 0.775 . Glukosinolaattien poistaminen ei vaikuttanut sulavuusarvoihin. Öpex-kăsitellyt rouheet sulivat yhtä hyvin tai hieman paremmin kuin kăsittelemättömăt rouheet: orgaaninen aine keskimäärin 0.669 vs. 0.680 ja vastaavasti raakavalkuainen 0.746 vs. 0.757 . Tällä havainnolla on kăytännoon merkitystä, koska samalla tavalla käsiteltyjă rouheita voidaan käyttäă rehuna sekă märehtijoille ettă yksimahaisille. Valkuaisen hyväksikäytőssä ei ollut eroja eri rouheiden tai erilaisten kăsittelyiden vălillă. 